\title{
Breves comentários sobre algumas obras publicadas em 2018
}

BRANDÃO, Carlos A.; FERNÁNDEZ, Victor Ramiro; RIBEIRO, Luiz Cesar de Queiroz (org.) Escalas espaciais, reescalonamentos e estatalidades: lições e desafios para América Latina. Rio de Janeiro: Letra Capital; Observatório das Metrópoles, 2018.

Esta coletânea é constituída de dez interessantes capítulos, além da introdução assinada por seus organizadores - e de um posfácio. A temática está devidamente traduzida pelo título, isto é, o conjunto de artigos que compõem a coletânea trata do protagonismo do Estado na reprodução das diversas escalas geográficas. Mas, especificamente, quem escreve sobre o que? Os autores (entre os 12, há apenas uma mulher) são conhecidos estudiosos britânicos - Bob Jessop, Erik Swyngedouw, Neil Brenner e Jamie Peck - e latino-americanos - Blanca Rebeca Ramírez Velázquez, Victor Ramiro Fernández e seis brasileiros - da "questão regional". O que une os artigos é a preocupação com a desconstrução da narrativa localista, a ideia de que é possível desenvolver "endogenamente" uma dada localidade/uma dada cidade ou uma certa região a partir de seus próprios ativos, desprezando o que se passa nas outras escalas e nos diversos níveis de governo. Em face dela, os autores propõem superar o discurso apologético do local e recuperar a escala nacional. Leitura recomendável!

DE SOUZA SANTOS, Boaventura. Construindo as Epistemologias do Sul: antologia essencial (2 vols.). Buenos Aires: CLACSO, 2018.

Boaventura de Souza Santos tornou-se conhecido nas ciências sociais brasileiras por solidarizar-se na produção de um conhecimento próprio, crítico do saber eurocêntrico. O livro em questão está sendo disponibilizado online por CLACSO em dois extensos volumes, ambos organizados por Maria Paula Meneses, João Arriscado Nunes, Carlos Lema Añon, Antoni Aguiló Bonet e Nilma Lino Gomes. O primeiro, que ultrapassa 690 páginas, tem duas partes principais: "Pensando desde o sul e com o sul" e "Teoria social para outro mundo possível". O segundo volume, prefaciado por Pablo Gentili, alcança 750 páginas e tem três partes principais: "Direito para outro mundo possível", "Democracia para outro mundo possível" e "Educação para outro mundo possível". Mesmo que os 31 textos reunidos nesses dois volumes sejam conhecidos e mesmo que os assuntos neles tratados possam, talvez, ter sido superados pelo "avanço" do conhecimento, a sua reunião e disponibilidade é uma homenagem não apenas ao seu autor, mas às/aos leitoras/es de qualquer época. 
MÉNDEZ, Ricardo. La telaraña financeira: una geografia de la financiarización y su crisis. Santiago: RIL Editores; Instituto de Estudios Urbanos y Territoriales UC, 2018.

O último livro de Ricardo Méndez, conhecido professor de geografia econômica da Universidade Complutense de Madrid, trata das implicações geográficas da crescente relevância do capital financeiro na economia mundial. Além da introdução, há seis densos capítulos - que somam 420 páginas. No primeiro, Méndez se debruça sobre a hegemonia do regime de acumulação financeirizado no contexto da globalização neoliberal. No segundo, os diversos atores financeiros são identificados e examinados de uma perspectiva geográfica. No terceiro, os fluxos financeiros são abordados a partir das redes que tecem e dos mercados em que se reproduzem. No quarto capítulo entram em cena loci específicos, como as cidades globais e os paraísos fiscais, em que as finanças estão "em casa". No quinto, são examinados os múltiplos impactos da globalização das finanças. E, no último capítulo, Méndez reflete sobre se as crises financeiras cada vez mais frequentes desembocam em uma crise sistêmica e se as alternativas à vista podem conduzir a práticas solidárias. Leitura recomendável!

ORANTES GARCÍA, José Rubén; CAL Y MAYOR, Araceli B. (org.) Justicia indígena, derecho de consulta, aunomías y resistencias. San Cristóbal de Las Casas/Chiapas: CIMSUR; Ciudad de México: UNAM, 2018.

Nesta bela coletânea sobre "direito indígena" sucedem-se, em pouco mais de 400 páginas, além da apresentação, 13 instigantes textos. Eles estão divididos em três partes principais: na primeira, "Justicia indígena y justicia estatal: campos de interacción en disputa", agrupam-se os cinco primeiros artigos; na segunda, "Derecho de consulta, resistencias y defensa de los bienes comunes", comparecem outros quatro artigos; e, na terceira, "Gobierno indígena, municipio y autonomías", encontram-se os últimos quatro artigos. Se, em separado, os artigos se debruçam sobre casos e situações específicas que se manifestam em diferentes pontos do território, em conjunto, eles oferecem uma leitura crítica e bastante atualizada da organização jurídica que alcança os povos indígenas no México. Aí se fica sabendo que, como no Brasil, megaprojetos ameaçam a existência de povos indígenas naquele país. E que, como no Brasil, povos indígenas daquele país também se empenham em uma longa e tenaz resistência. E que lutam por uma sonhada e justa autonomia. Vale a leitura!

PORTO, Jadson L. R.; CAVLAK, Iuri; NORONHA, Andrius E. (org.) Faces da fronteira: entre histórias e espaços, encontros e desencontros. Macapá: EDUNIFAP, 2018. 
Esta pequena coletânea, que cabe em menos de 150 páginas, reúne sete artigos, precedidos de uma breve apresentação. O primeiro é um clássico de Christian Topalov, "Petite histoire de la frontière, en France" - que, por assim dizer, serve de "guia espiritual" para os seis seguintes (todos em português). A temática comum é, como anuncia o seu título, a fronteira, ou melhor, a(s) fronteira(s) do norte brasileiro. Certamente, pode-se ler cada um dos seis textos em separado. Neles são examinadas, por exemplo, a presença das forças armadas, a fragmentação da natureza na Amazônia, as relações entre duas unidades federativas, a questão indígena etc. Não obstante, todos esses problemas se interrelacionam por se referirem, todos, à temática da fronteira. De fato, se bem a coletânea consista em um mosaico de aspectos aparentemente isolados uns dos outros, ela funciona como um amálgama que, em torno da problemática da(s) fronteira(s) do norte do Brasil, une prodigiosamente entre si os artigos que a integram. Esta parece ser sua principal virtude. E o que desafia à sua leitura.

POUPEAU, Franck; RAZAFIMAHEFA, Lala; ROBERT, Jérémy; MERCIER, Delphine; MASSARDIER, Gilles; JACOBY, Pedro Roberto. Water conflicts and hydrocracy in the Americas: coalitions, networks, policies. São Paulo: IEE-USP, 2018.

Aqui se tem, em pouco mais de 400 páginas, uma oportuna coletânea sobre a questão da água. Ou melhor: sobre os múltiplos conflitos em torno dos recursos hídricos na América. São 12 capítulos distribuídos por quatro partes distintas: a primeira trata de desigualdades e conflitos relativos à água; a segunda, de reconfigurações institucionais e participação cidadã; a terceira, da "crise" da água, propriamente; e a última (compreendendo dois capítulos), das considerações finais. Antecedem-nos um prólogo e uma introdução - que traz dois anexos: o primeiro informa sobre a metodologia adotada, o segundo apresenta a política brasileira de recursos hídricos. Ao final há, ainda, dois anexos (o primeiro, uma lista dos autores, o segundo, figuras explicativas da perspectiva analítica). Onde, porém, está o busílis que anima esta publicação? Na introdução e na conclusão, ambas redigidas por seus organizadores. A introdução enfatiza, precisamente, a problemática dos conflitos da água. E a conclusão faz um eloquente apelo à ecologização da gestão dos recursos hídricos. Vale a leitura! 